\title{
A New Learning Model on Physical Education: 5E Learning Cycle
}

\author{
Halil Evren Senturk ${ }^{1, *}$, Huseyin Camliyer ${ }^{2}$ \\ ${ }^{1}$ Faculty of Sports Sciences, Mugla Sitki Kocman University, Turkey \\ ${ }^{2}$ School of Physical Education and Sports, Celal Bayar University, Turkey
}

Copyright $(\mathcal{C} 2016$ by authors, all rights reserved. Authors agree that this article remains permanently open access under the terms of the Creative Commons Attribution License 4.0 International License

\begin{abstract}
Many fields of education at the moment, especially in physical and technological educations, use $5 \mathrm{E}$ learning cycle. The process is defined as five "E"s. These represent the verbs engage, explore, explain, elaborate and evaluate [1]. The literature has been systematically reviewed and the results show that the 5E learning cycle is an untested model in physical education. Especially, positive or negative effects of the 5E learning cycle in physical education are unknown. This study is important for relevant literatures in order to be the first study about the conceptual constructive of the 5E learning cycle in physical education. Thus, the purposes of this study are to conceptualize the 5E learning cycle in physical education as a new constructivist approach and to prepare sample teaching plans for use in physical education classes. Sample teaching plans about the 5E learning cycle have been prepared by authors and are ready to use in physical education and sport teaching. For example, a physical education teacher who wants to teach basic concepts about the human physiology (like heartbeat, breath, fatigue, etc.) or skills, can use the $5 \mathrm{E}$ learning cycle. First of all, in engaging stage, to draw the students' attention, teachers can ask considerable questions about daily life, and an amazing event or they give students the chance to think about some visual elements without making any explanation about the topic (What is the heartbeat?, Why do people get tired?, Students could be asked to place their hands beneath their left breast and tell what they feel etc.). In exploring stage, students should be involved in activities that allow them to have first-hand experience in the phenomena being observed i.e. heart beats. In order to build relevant experiences of the subject matter, models can be provided by the teacher, which will enable the learners to manipulate. Learners can communicate and share their ideas among themselves. The process is being facilitated by the teacher. In the explanation stage, the students are required to explain what they have learned by using their own words after the physical activity, by telling the results they reached, the observations they made and their ideas as well as the things that they noticed. In elaborating stage, using the lessons learnt in the previous stages, the students are encouraged to build and expand upon it to solve the problems in the physical education. They are provided to see new question
\end{abstract}

types about the new taught subject and the students are expected to give answers to these questions. The last stage (evaluate), should be a continuous process which occurs in all the stages to determine that learning objectives have been achieved and to avoid misconceptions. Any evaluation tool can be used (observations, checklists, interviews etc). Student's physical performances and his developing degree in the process are taken into consideration. In this context, $5 \mathrm{E}$ learning cycle can also be used to teach concepts on physical education and sport teaching as an applied science of education. $5 \mathrm{E}$ learning cycle that is being used as a different model can be applied by competent physical education teachers in the course of physical education lessons. As a conclusion, the plans prepared may be applied by authors, teachers or independent researchers who want to study on this model and this study will be a new idea about the constructivist approach to teaching physical education.

Keywords 5E, Learning Model, Teaching, Physical Education, Constructive Approach

\section{Introduction}

Researchers, currently studying curricula in physical education, have suggested that physical education programs today are similar to programs of past decades. Curriculum implementation may be the major catalyst in creating change in physical education [2].

As with educational reform in the wider education context, physical education has evolved from three radical reforms and extinction in its history [3]. The first, up until the 1950s held the dominant view of physical education as gymnastics. Between 1950s and 1990s, the idea of physical education shifted from physical education as gymnastics to physical education as sport-techniques. The effects of social conditions such as introduction of mass secondary education, contingent constraints of institutionalized schooling, and a greater number of male physical educators entering the profession during the 1950s marked this change [3]. Finally, reform after 1990 evolved as a result of emerging researchers who indicated that increasing non-communicable diseases, 
such as cardiovascular disease, diabetes, cancer, obesity rates and physical inactivity had become the most important public health issues globally [4]. The alarming rates of overweight and obese children need to be addressed by health educators and professionals. Increasing regular physical activity is widely accepted as an effective preventive measure for a variety of health risk factors across all ages and genders [5]. Considering these issues, current international and national physical education standards have stated that "regular physical activity participation", "performing and maintaining health enhancing physical activity" and "internalizing health related physical fitness concepts" are critical to provide a guide for school physical education curricula [6].

The current Turkish curriculum is based on the principle that "every child must be physically active". So then in physical education lesson, teacher must use an interactive learning method for the active children. In variety fields of education at the present time, most especially in physical and technological educations, a different interactive learning method named 5E learning cycle is being used by many teachers as well. 5E Learning cycle is one of the constructivist approach models, developed by the BSCS group. It consists of five phases; engagement, exploration, explanation, elaboration and evaluation [7].

The literature has been systematically reviewed and the results showed that the $5 \mathrm{E}$ learning cycle is an untested model in physical education. Especially, positive or negative effects of the $5 \mathrm{E}$ learning cycle in physical education are unknown. This study is important for relevant literatures in order to be the pioneering studies on the concept of constructive 5E learning cycle in physical education. Thus, the purposes of this study are to conceptualize the $5 \mathrm{E}$ learning cycle in physical education as a new constructivist approach and to prepare sample teaching plans for use in physical education classes. Sample teaching plans about the $5 \mathrm{E}$ learning cycle have been prepared by authors and are ready to be used in physical education and sport teaching. For example, a physical education teacher who wants to teach basic concepts about the human physiology (like heartbeat, breath, fatigue, etc.) or any basic motor skills, can use this model of the 5 "E"s. In this context, the present study intends to serve as a basis for future research on $5 \mathrm{E}$ learning cycle in physical education.

Table 1. Sample Lesson Plan (Physical Activity Habit)

\begin{tabular}{|c|c|}
\hline Learning Domain & Physical Activity Habit \\
\hline Sub-Learning Domain & Relationship between Physical Activity and Circulatory System \\
\hline Learning Objectives & Developing evaluable information about Physical Activity and Circulatory System \\
\hline Course Time & 1 hour \\
\hline Skills & Reasoning, overarching \\
\hline Gains & Learning heartbeat, using in social life \\
\hline Methods and Techniques & Examination and exploring, learning by doing \\
\hline \multicolumn{2}{|r|}{ Engaging } \\
\hline \multicolumn{2}{|r|}{$\begin{array}{l}\text { Teacher asks questions as follows; } \\
\text { ost important of them?" } \\
\text { ?" } \\
\text { the heartbeat?, Why do people get tired?, etc.). }\end{array}$} \\
\hline \multicolumn{2}{|r|}{ Exploring } \\
\hline \multicolumn{2}{|c|}{$\begin{array}{l}\text { Teacher asks students to run } 2 \text { tours round the school garden. After, requests students to feel their heart beat and asks these questions; } \\
\text { 1. "Are you feeling your heartbeat?" } \\
\text { 2. "Do you know why your hearth beat is faster?" } \\
\text { 3. "Which other reactions did you feel like faster breathing, sweltering, warming up, etc?" And teacher wants students to discuss each other and to } \\
\text { tell a story about these situations. }\end{array}$} \\
\hline \multicolumn{2}{|c|}{ Explaining } \\
\hline \multicolumn{2}{|c|}{$\begin{array}{l}\text { Teacher wants students to run } 5 \text { tours around the school garden at this time. After heartbeats of students h } \\
\text { 1. "How many is your heartbeat?" } \\
\text { 2. "Did you feel reactions we talked before?" } \\
\text { 3. } \\
\text { 4. "Are you tired and / or thirsty?" } \\
\text { 5. "Do you want to play a game or do physical activity tirelessly?" } \\
\text { Teacher lets them think critical and ask questions. So, teacher provides them with a clear understanding. }\end{array}$} \\
\hline \multicolumn{2}{|c|}{\begin{tabular}{|ll} 
Elaborating \\
\end{tabular}} \\
\hline \multicolumn{2}{|c|}{$\begin{array}{l}\text { Teacher gives them chance to use their knowledge and asks questions for reinforcement; } \\
\text { 1. "Who is your favorite athlete?" } \\
\text { 2. "What do you think that these athletes are tired when they run or do physical activity as much as you are?" } \\
\text { 3. } \\
\text { Teacher lets them think critically and answer the questions. After then students are required to discuss among themselves about relationship between } \\
\text { physical activity habits and heartbeat. Finally, the teacher teaches the relationship between these concepts so that these concepts will be thoroughly } \\
\text { learned by the students. }\end{array}$} \\
\hline \multicolumn{2}{|r|}{ Evaluation } \\
\hline $\begin{array}{l}\text { this stage, the students should } 1 \\
\text { omposition about which activity } \\
\text { or physical activity habits of the }\end{array}$ & $\begin{array}{l}\text { nship between physical activity habits and circulation system. Teacher wants them to write a } \\
\text { arly and talk about it with their families. Teacher evaluates awareness what teacher wants to rais }\end{array}$ \\
\hline
\end{tabular}


Table 2. Sample Lesson Plan (Any Basic Motor Skill Learning)

\begin{tabular}{|c|c|}
\hline Learning Domain & Any Basic Motor Skill Learning \\
\hline Sub-Learning Domain & Any Motor Skill \\
\hline Learning Objectives & Developing observable motor skills in physical education \\
\hline Course Time & 1 hour \\
\hline \multicolumn{2}{|l|}{ Skills } \\
\hline Gains & \multirow[t]{2}{*}{ Teacher must decide which motor skill students should learn. } \\
\hline \multirow{2}{*}{\multicolumn{2}{|c|}{ Methods and Techniques }} \\
\hline & \\
\hline \multicolumn{2}{|c|}{$\begin{array}{l}\text { First of all, in engaging stage, to draw the students' attention, teacher asks considerable questions about daily life, sport competitions, famous athletes } \\
\text { and an amazing event or they give students the chance to think about some visual elements without making any explanation about the topic (Who is the } \\
\text { fastest man in the world?, Have you ever watched a basketball match in your life?, etc.). }\end{array}$} \\
\hline \multicolumn{2}{|c|}{ Exploring } \\
\hline \multicolumn{2}{|c|}{ In exploring stage, students offer activities about the physical activity and they are provided to reach the information on their own. } \\
\hline \multicolumn{2}{|c|}{ Explaining } \\
\hline \multicolumn{2}{|c|}{$\begin{array}{l}\text { The students are required to explain what they learned by their own sentences after the physical activity, by telling the results they reached, the } \\
\text { observations they made and their ideas as well as the things that they noticed. The students can share their experiences among themselves. The teacher } \\
\text { in this stage is a facilitator. }\end{array}$} \\
\hline \multicolumn{2}{|c|}{\begin{tabular}{ll|} 
Elaborating \\
\end{tabular}} \\
\hline \multicolumn{2}{|c|}{$\begin{array}{l}\text { In elaborating stage, the students are encouraged to practice and solve the problems about this skill. They are going to do new activity types about the } \\
\text { new topic taught and the students are expected to give answers to questions like; } \\
\text { S: "Can we use a different throwing technique for the shot put?" } \\
\text { S: "Are there any different styles of serving the ball in volleyball?" } \\
\end{array}$} \\
\hline \multicolumn{2}{|c|}{$\begin{array}{ll}\text { Evaluation } \\
\end{array}$} \\
\hline $\begin{array}{l}\text { And in the last stage (evaluate), by e: } \\
\text { observed. These observations made } \mathrm{t} \\
\text { are taken into consideration. In this } \mathrm{s} \\
\text { taught based on the learning objectiv }\end{array}$ & $\begin{array}{l}\text { ents make in their school and physical activities, the students' learning levels are } \\
\text { process. Student's physical performances and his developing degree in the process } \\
\text { on tools to be used either interview, observation or checklist etc. to evaluate the topic } \\
\text { lesson. }\end{array}$ \\
\hline
\end{tabular}

\section{Methodology}

In this section, two sample lesson plans have been prepared in order to teach the basic concepts and skills in physical education. In preparation phase of these plans, the authors have taken care of all phases of $5 \mathrm{E}$ learning cycle.

\section{Discussion and Conclusions}

While there are many studies on $5 \mathrm{E}$ learning cycle in the world, in Turkey these studies are limited and are only on science disciplines and none on physical education.

The primary purpose of this study was to adapt $5 \mathrm{E}$ learning cycle as a new learning model to physical education. The other purpose was to conceptualize the $5 \mathrm{E}$ learning cycle in physical education as a new constructivist approach and to prepare sample teaching plans for use in physical education classes. Sample teaching plans about the 5E learning cycle have been prepared by authors and are ready to use in physical education and sport teaching. For example, if a physical education teacher wants to teach basic concepts about the human physiology (like heartbeat, breath, fatigue, etc.) or skills, he or she can use the 5 "E" model.

In this context, $5 \mathrm{E}$ learning cycle can also be used for teaching concepts on physical education and sport teaching as an applied science of education. 5E learning cycle that is being used as a different model can be applied by competent physical education teachers in the course of physical education lessons.

In conclusion, the lesson plans prepared may be applied by authors, teachers or independent researchers who want to study on this model and this study will be a new idea about the constructivist approach to teach physical education.

\section{REFERENCES}

[1] Bybee, R. (2001). The Five E's from Roger Bybee. Biological Curriculum Science Study (BSCS). Retrieved May 6, 2014, from http://www.miamisci.org/ph/lpintro5e.html

[2] Ward, P. (1999). Designing of the Saber-Tooth project. Journal of Teaching in Physical Education, 18(4), p. 403-416.

[3] Kirk, D. (2010). Physical Education Futures. London: Routhledge. p.6-7.

[4] U.S. Department of Health and Human Services (2000). Physical activity and health: a report of the Surgeon General. Atlanta, GA: Centers for Disease Control and Prevention and Health Promotion.

[5] Tremblay, M. S.; Warburton, D. E. R.; Janssen, I., Paterson, D. H., Latimer, A. E., Rhodes, R. E., Kho, M. E., Hicks, A., LeBlanc, A. G. Zehr, L. Murumets, K., \& Duggan, M. (2011). New Canadian directives on physical activity matters, Applied Physiology Nutrition and Metabolism, 36(1), 47-58. 
[6] NASPE (2004). Moving into the Future, National Standards for Physical Education for Physical Education. Oxon Hill, MD: McGraw-Hill Higher Education.

[7] Bybee, R.W., Taylor, A. J., Gardner, A., Scotter, P.V., Powell,
J.C., Westbrook, A. \& Landes, N. (2006). The BSCS 5E instructional model: Origins, effectiveness and applications. Retrieved May 20, 2014, from http://www.bscs.org/pdf/bscs5eexecsummary.pdf 